\title{
Implications of the study of subglacial volcanism and glaciovolcanic cave systems
}

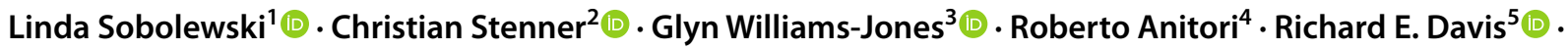 \\ Andreas Pflitsch ${ }^{1}$ (1)
}

Received: 14 July 2021 / Accepted: 17 December 2021 / Published online: 12 February 2022

(c) The Author(s) 2022

\begin{abstract}
Glacial environments can have significant impacts on the surrounding landscape and nearby populations when affected by volcanic activity. As such, glaciovolcanic interactions and related hazards have received substantial attention during the last few decades. In contrast, the study of void spaces created by these interactions - glaciovolcanic cave systems-remains underrepresented. This review outlines the global distribution of glaciovolcanic caves and describes examples of both historical and ongoing research advances, most of which are limited to volcanoes of the Cascade Volcanic Arc and Antarctica. Examples range from a largely static fumarolic ice cave system in the crater of Mount Rainier to glaciovolcanic cave genesis and evolution in the crater of Mount St. Helens, where the advancing glacier ice is interacting with ongoing fumarolic activity and generating new cave systems. This review includes various volcanic subfields and also brings together additional disciplines including speleology, microbiology, and astrobiology. Due to the importance of glaciovolcanic caves in the hydrothermal cycle of volcanic systems, the global fight against antibiotic resistance, and their implications for understanding volcano-ice interactions beyond Earth, research on these systems is expanding. Kamchatka, Alaska, and Iceland have notable potential for further studies, while known research sites still hold open questions, including better understanding of the environmental parameters affecting cave genesis and persistence, the effect of glaciovolcanic cave development on underlying hydrothermal systems, and cataloging the biodiversity of glaciovolcanic cave environments.
\end{abstract}

Keywords Volcano-ice interactions · Cascade Volcanic Arc $\cdot$ Antarctica $\cdot$ Astrobiology $\cdot$ Antibiotic resistance

\section{Zusammenfassung}

Glazial beeinflusste Gebiete können in Verbindung mit vulkanischer Aktivität große Auswirkungen auf die umliegende Landschaft und nahegelegene Ansiedlungen haben. Aufgrund dessen haben Vulkan-Eis-Interaktionen und damit verbundene Gefahren innerhalb der letzten Jahrzehnte große Beachtung gefunden. Im Gegensatz dazu sind Studien zu Hohlräumen im Eis (sogenannten vulkanischen Gletscherhöhlen), die durch diese Interaktionen entstehen, unterrepräsentiert. Dieser Artikel zeigt das weltweite Vorkommen vulkanischer Gletscherhöhlen auf und beschreibt Beispiele vergangener und aktueller Forschung, wobei diese vor allem auf Vulkane des Kaskadengebirges und der Antarktis beschränkt ist. Beispiele reichen dabei von einem relativ statischen System vulkanischer Gletscherhöhlen in Firneis, wie sie am Mount Rainier vorkommen, bis hin

This paper constitutes part of a topical collection: Looking Backwards and Forwards in Volcanology: A Collection of Perspectives on the Trajectory of a Science

Editorial responsibility: K.V. Cashman

Linda Sobolewski

linda.sobolewski@ruhr-uni-bochum.de

1 Institute of Geography, Ruhr-University Bochum, Bochum, Germany

2 Alberta Speleological Society, Calgary, AB, Canada
3 Centre for Natural Hazards Research, Department of Earth Sciences, Simon Fraser University, Burnaby, BC, Canada

4 Department of Biology, Clark College, Vancouver, WA, USA

5 Astromaterials Research and Exploration Science, Texas State University / NASA Johnson Space Center, Houston, TX, USA 
zur Entstehung und Entwicklung neuer Höhlensysteme im Krater des Mount St. Helens, wo das fortschreitende Gletschereis mit anhaltender fumarolischer Tätigkeit interagiert und dadurch neue Höhlen entstehen lässt. Dieser Artikel umfasst diverse vulkanische Arbeitsbereiche, aber schließt ebenfalls andere Disziplinen wie die Speleologie, Mikro- und Astrobiologie ein. Aufgrund der Bedeutung vulkanischer Gletscherhöhlen für den hydrothermalen Kreislauf von vulkanischen Systemen, den globalen Kampf gegen Antibiotika-Resistenz sowie ihrer Bedeutung, Vulkan-Eis-Interaktionen abseits des Planeten Erde zu verstehen, erfährt die Erforschung dieser Systeme steten Zuwachs. Kamtschatka, Alaska und Island haben hohes Potenzial für weitere Forschung, während bisher bekannte Gebiete nach wie vor Fragen offen lassen. Diese beinhalten ein besseres Verständnis von natürlichen Faktoren, die Entstehung und Fortbestehen der Höhlen beeinflussen, Auswirkungen vulkanischer Gletscherhöhlensysteme auf das darunterliegende Hydrothermalsystem sowie eine Katalogisierung der Biodiversität dieser Umgebungen.

\section{Introduction}

The vulnerability of modern society to volcano-ice interactions during volcanic eruptions has been demonstrated by several eruptions since 1980, including Nevado del Ruiz (Colombia) in 1985 (Pierson et al. 1990), Gjálp (Iceland) in 1996 (Gudmundsson et al. 1997), and Eyjafjallajokull (Iceland) in 2010 (Langmann et al. 2012). Glaciovolcanism, i.e., the interaction of heat from the Earth's interior with various types of ice masses (Smellie and Edwards 2016), can be found worldwide with 245 identified Holocene volcanoes potentially impacting or being impacted by surrounding ice (Edwards et al. 2020).

A rarely studied phenomenon, however, is the formation of void spaces beneath ice - glaciovolcanic caves (Florea et al. 2021b). Despite significant potential for their existence amongst the active, glaciated volcanoes identified by Edwards et al. (2020), few cave systems have been confirmed (Fig. 1). Although similar mechanisms initiate cave genesis in glacier ice, e.g., geothermal activity, water runoff, or glacier movement (Badino et al. 2007; Benn and Evans 2010), each system displays unique characteristics (Fig. 2). Mount Rainier (USA), for example, hosts a melt- and condensate-formed subglacial lake that is located within the East Crater Cave (Florea et al. 2021a) (Fig. 2a). Mount Erebus (Antarctica) is famous for its ice chimneys (Fig. 2b) and caves that exhibit delicate coatings of ice crystals (Fig. 2c). While studies of these caves date back to the 1970s (e.g., Kiver and Mumma 1971; Kiver and Steele 1975; Giggenbach 1976), more recent study sites include Mount Hood's Sandy Glacier (Pflitsch et al. 2017), as well as the newly formed crater of nearby Mount St. Helens, where cave systems circumnavigate the 2004-2008 lava dome (Stenner et al. 2021). Although glacial retreat on Mount Hood has led to shrinking passages (Fig. 2d), the glacier in the crater of Mount St. Helens is expanding, as are its cave systems, revealing many tephra layers in ice walls and ceilings (Fig. 2e). Glaciovolcanic caves at Mount Meager in Canada (e.g., Venugopal et al. 2017; Unnsteinsson et al. 2021a, b) display voluminous chimney morphologies (Fig. 2f). Other recent studies have examined Mount Rittmann and Mount Melbourne in Antarctica (e.g., Fraser et al. 2018; Cannata et al. 2018; Gambino et al. 2021).

Because glaciovolcanic cave formation starts as a subglacial process, detection difficulties have limited research. Recent work on glaciovolcanic cave systems, however, has considered their relevance to hydrothermal cycles and the unique microclimates within the caves themselves (Florea et al. 2021a; Pflitsch et al. 2017); has investigated them as analogs for understanding life on other solar system bodies (e.g. Tebo et al. 2015; Curtis 2020; Davis et al. 2020); and has used them for testing robotic technologies for the exploration of similar planetary environments (Cushing 2012; Duncombe 2018). Moreover, their oligotrophic nature combined with geothermal influences have led to the establishment of ecosystems which harbor unique, photosynthesis-independent microbial communities with potential applications in the global fight against antibiotic resistance (Tebo et al. 2015; Anitori et al. 2021).

This paper summarizes the history of glaciovolcanic cave research and illustrates its trajectory from early beginnings in the nineteenth century to present research and ongoing studies. Here, we showcase significant research results and discoveries, present prospective avenues for future study, and assess possible progress over the next decade.

\section{Looking back: the development of glaciovolcanic cave research}

Studying glaciovolcanic caves has been limited by accessibility, short timeframes in which fieldwork is possible, extensive logistical challenges, and the specialized skills (e.g., ice-climbing and mountaineering) that are required to work in these extreme environments.

A description of a deep cavern "formed by heat" descending into the crater ice at the summit of Mount Rainier was recorded during the first ascent in 1870 (Stevens 1876). Detailed studies began a century later with descriptive phenomenological research carried out by Kiver and Mumma (1971) and Kiver and Steele (1975). Simultaneously, Lyon and Giggenbach (1974) described fumarolic ice towers on Mount Erebus which was followed by the first detailed study of a related geothermal ice cave at Erebus (Giggenbach 1976). These examples were extended only after unrest and renewed glacial accumulation between 1981 and 1996 in the crater of Mount St. Helens created a new system of caves in 


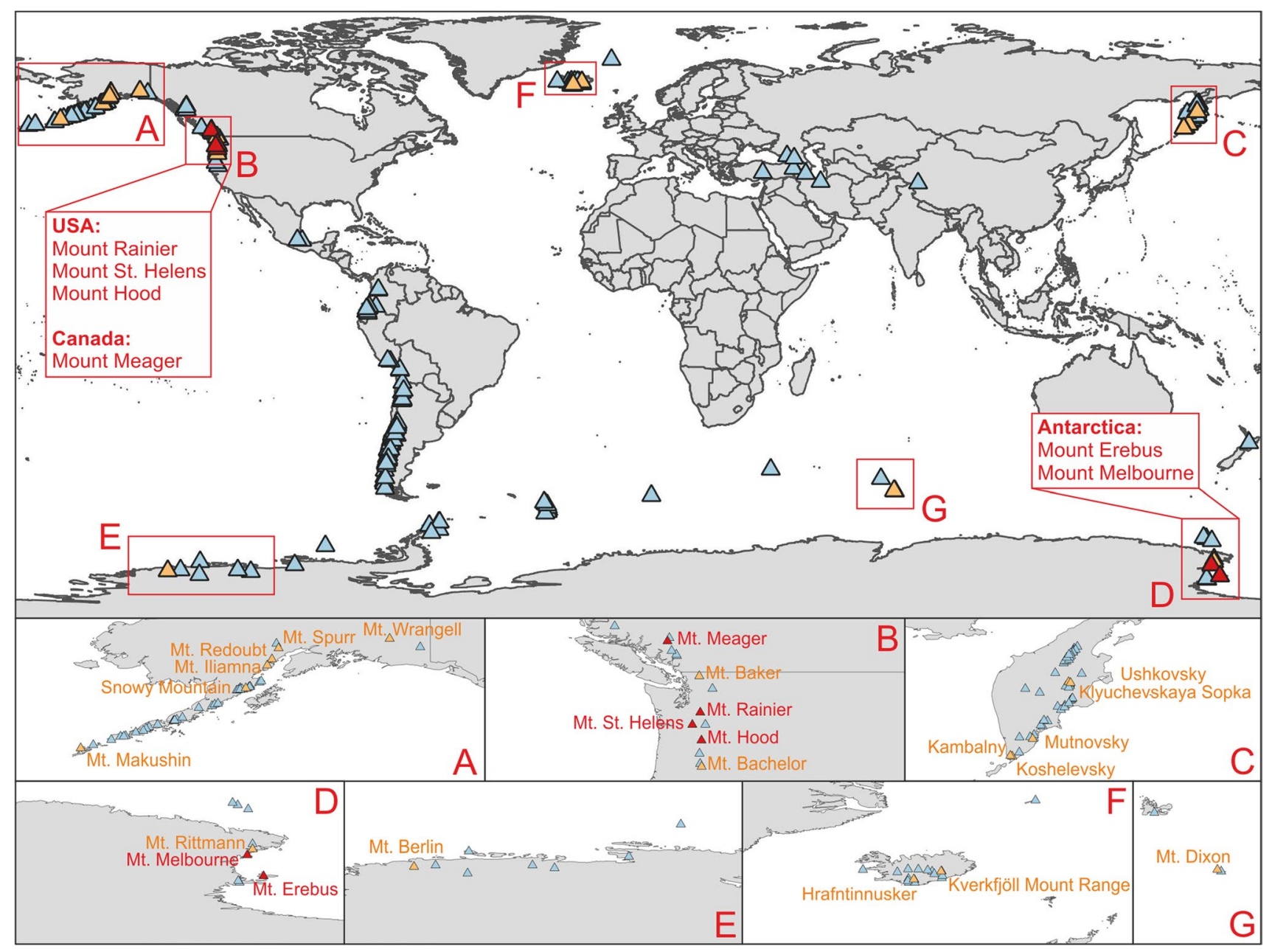

Fig. 1 Global distribution of glaciated Holocene volcanoes and glaciovolcanic caves. Triangles represent a total of 245 glaciated Holocene volcanoes after Edwards et al. (2020). Red triangles show volcanoes with confirmed cave systems and ongoing or previously performed studies. Orange triangles show volcanoes or volcanic systems likely hosting glaciovolcanic cave systems. Blue triangles represent remaining glaciated Holocene volcanoes with no evidence for cave systems or insufficient data firn surrounding the 1980-1986 lava dome (Anderson et al. 1998; Anderson and Vining 1999).

During the next two decades (2000-2020), glaciovolcanic cave research has expanded to integrate field work, laboratory studies, and theoretical approaches. On Mount Rainier (USA), stable isotope, gas, and geochemical analyses by Zimbelman et al. (2000) illustrated that the hydrothermal system consists of meteoric water reservoirs which are affected by the underlying magmatic system. Here, hydrothermal alteration is significant and leaves the edifice prone to future collapses (Zimbelman et al. 2000). Related studies on Mount Rainier were carried out by Le Guern et al. (2000) to investigate fumarole gas compositions and soil mineralogy within the caves. Increasing awareness of the potential impact of volcanic hazards on densely populated areas worldwide started in the 1990s, expanding interest in cave dynamics as precursor signals to volcano-related risks. In 1987, Mount Rainier was designated as one of 16 Decade Volcanoes, identified by the International Association of Volcanology and Chemistry of the Earth's Interior (IAVCEI), to increase public awareness and promote further research (Newhall 1996). Importantly, Zimbelman et al. (2000) hypothesized that on-site analyses of fumarole gases and seismic monitoring of ice caves may determine the extent of hydrothermal alteration occurring at depth and its potential effects on future edifice failures and associated hazards.

Examples from Mount Erebus, Antarctica, were presented in the decade 2010-2020. Here, Curtis and Kyle (2011) used fiber optic distributed temperature sensing within a glaciovolcanic cave on Mount Erebus to explore the extent of diffuse degassing in response to barometric pumping while Curtis (2016) investigated chemical and 

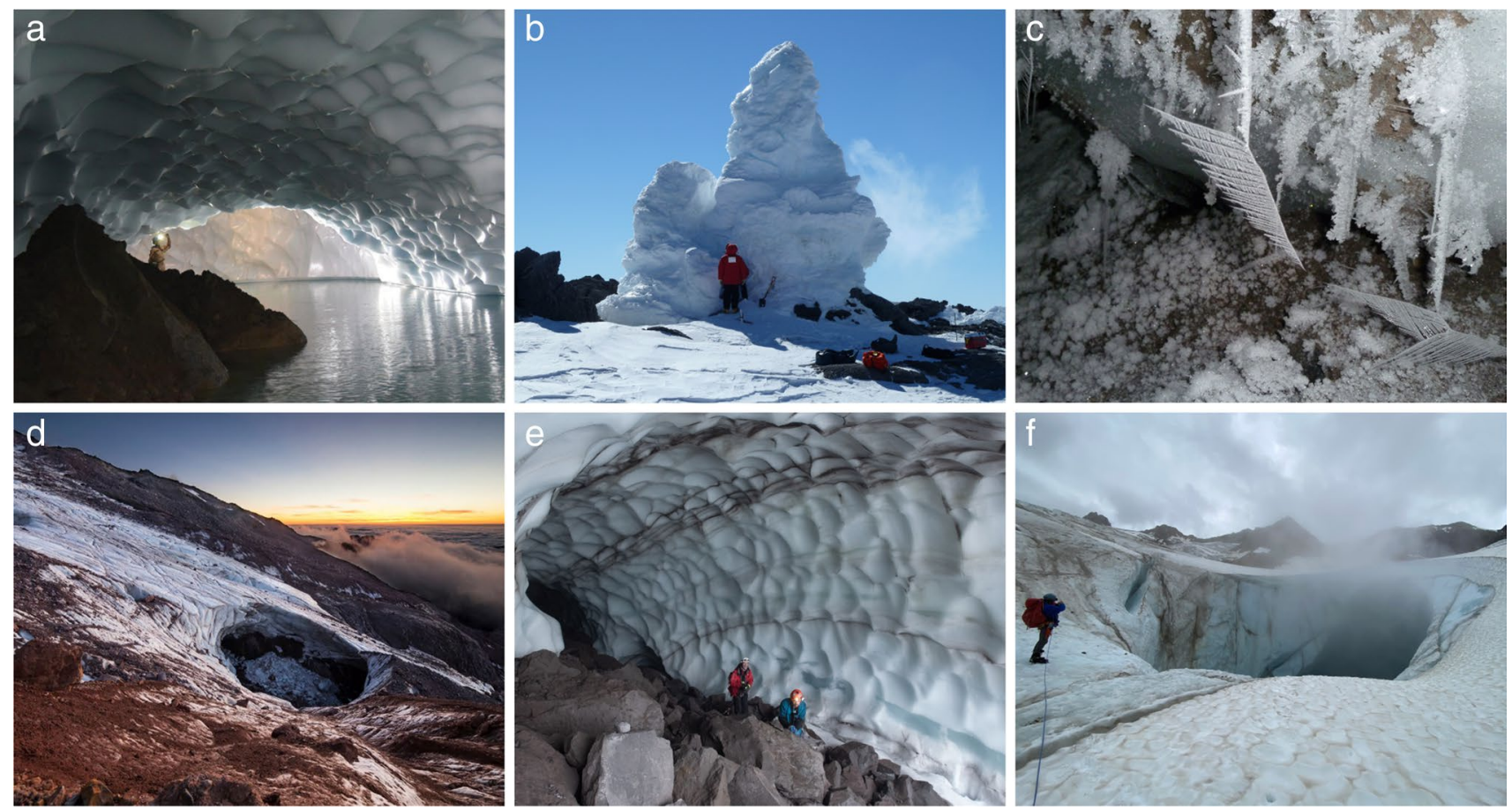

Fig. 2 Examples of glaciovolcanic cave systems being studied in the Cascade Volcanic Arc, USA/Canada, and Antarctica. a The subglacial Lake Adélie in East Crater Cave, the highest elevation lake in the USA, Mount Rainier, 2015. Photo: Tom Wood (used with permission). b Ice chimney above the entrance to Harry's Dream Cave, Mount Erebus, 2010. c Crystals inside Hubert's Nightmare Cave, Mount Erebus, 2010. Photos: Roberto Anitori. d Cerberus Moulin, part of Pure Imagination Cave on Sandy Glacier, Mount Hood, 2015.

isotopic compositions of snow samples and concluded that the observed magmatic signature derived from the persistent gas plume fed by the permanent lava lake. Ilanko et al. (2019) examined the modification of volcanic gases measured in Mount Erebus caves and showed that gas emissions were dominated by air with spatially or temporally varying amounts of volcanic $\mathrm{CO}_{2}$, indicating extensive circulation of air through the volcanic edifice. Finally, the first report of glaciovolcanic caves as a unique environment for microbiological studies was described by Tebo et al. (2015), with the recognition of dark, oligotrophic volcanic ecosystems (DOVEs) as habitats for extremophile microorganisms.

\section{Understanding glaciovolcanic caves: a multi-disciplinary problem}

Studies currently in progress focus on questions that include:

- What factors influence glaciovolcanic cave system formation and longevity?
Due to glacier melt, a large amount of ice has collapsed, undercutting the south side of the Moulin and leaving rather thin sections of ice. Photo: Brent McGregor (used with permission). e Largest entrance to Ghidorah Cave, Mount St. Helens, 2019. Tephra layers characterize ice walls and ceilings. Photo: Eric Guth (used with permission). f Glaciovolcanic chimney, Mount Meager, 2021. Photo: Christian Stenner

- How do glaciovolcanic caves differ from glacier caves in non-volcanic settings?

- What effects do glaciovolcanic cave dynamics have on underlying hydrothermal systems?

- How can glaciovolcanic caves help us to understand life on other solar system bodies?

To understand glaciovolcanic cave environments requires expertise that spans volcanological, speleological, glaciological, climatological, and biological disciplines. Each discipline reflects a puzzle piece that is necessary to identify complex interrelationships and mechanisms.

Glacier caves in general are defined as caves that form inside the ice mass of a glacier or ice plug, primarily formed by water (Sugden and John 1976; Gulley and Fountain 2019). Glacier caves can form by glacier movement, temperature or density gradients, or Venturi effects (Badino et al. 2007; Benn and Evans 2010). Cuffey and Paterson (2010) also explore the role of separation pressure and surface roughness as a condition for cavity formation. An additional consideration in volcanic settings is geothermal activity (Florea et al. 2021b). Whereas knowledge of formation and genesis of englacial conduits and glacier caves is broad 
(e.g., Holmlund 1988; Gulley 2009; Gulley and Fountain 2019), a comprehensive understanding of these processes in volcanic settings remains limited (Florea et al. 2021b).

\section{Geospatial knowledge and the physical environment of glaciovolcanic caves}

To understand the geospatial and physical parameters of a cave system, physical exploration and survey data are needed (Sobolewski et al. 2022). Studies of glaciovolcanic cave systems reveal passages displaying balance between ice ablation and accumulation along with dynamic areas where cave structure changes annually, and areas with variable potential for hazardous atmospheres (Stenner et al. 2021; Florea et al. 2021b). Early glaciovolcanic cave maps had a simple layout (e.g., Fig. 7 in Anderson et al. 1998), but today 3D maps and volume estimates (e.g., using COMPASS software) are possible and fieldwork is facilitated by technological advances (e.g., DistoX) and software for in situ spatial visualization (e.g., Topodroid). High spatial resolution cameras can record detailed cave characteristics. While structure from motion (SfM) photogrammetric imaging has been used inside the caves (Curtis 2016), ultrasonic anemometers have been deployed to detect local wind regimes (Pflitsch et al. 2017). We have also deployed LIDAR systems to provide detailed mapping of cave interiors (Stenner, unpublished data), as well as MultiGas sensors to measure in situ gas concentrations (Sobolewski, unpublished data). Analysis and interpretation of data generated by these new techniques promises to provide significant insights into the complex physical/abiotic interrelationships that exist in glaciovolcanic cave systems, many of which are still only poorly understood.

Modern mapping tools have been used to describe the morphology of the newly formed caves in the crater of Mount St. Helens (Stenner et al. 2021), to show that climatological influences and mechanisms reinforced the persistent hazardous atmospheres within the Mount Rainier cave network (Stenner et al. 2022) and to demonstrate that both long-term static passages and dynamic cave passages exist, influenced by seasonal weather, passage collapse, and cave microclimates (Stenner et al. in review). To fully explain speleogenesis and to assess morphological changes, factors such as geothermal heat fluxes, their combination with cave microclimates, and external weather also need to be considered. One feature that distinguishes glaciovolcanic caves from non-volcanic glacier caves is that cave air temperatures and air pressures increase in winter, initiating cave expansion (Florea et al. 2021a; Sobolewski et al. 2022). In volcanic settings, seasonal snowfall and the resulting closure of cave entrances prevent warm air, heated by fumarolic activity, from escaping (Pflitsch et al. 2017; Florea et al. 2021a). Thus, melting processes inside the caves increase periodically, which could accelerate hydrothermal alteration of the edifice (Florea et al. 2021a). It is not yet clear, however, whether changes in glaciovolcanic cave temperatures and pressures can be associated with, and used to track, changes in volcanic activity, or are a result of seasonal rainfall and snowmelt affecting both the hydrothermal and cave system.

Some caves are dangerous and access is challenging, limiting cave-entry for field analysis. One example is at the Mount Meager Volcanic Complex in British Columbia, where concentrations of $\mathrm{H}_{2} \mathrm{~S}$ and $\mathrm{CO}_{2}$ are high. As a result, current research is focusing on numerical modeling of cave formation (Unnsteinsson et al. 2021b) and analytical approaches to assess the morphologies of glaciovolcanic caves and chimneys (Unnsteinsson et al. 2021a). Combining speleology, climatology, and volcanology to assess mechanisms of glaciovolcanic cave formation and conditions can also provide context for investigations of these extreme environments as an abode of life.

\section{Searching for subglacial life influenced by volcanic processes}

Increasing awareness of the capacity of cave environments to sustain rare microbial communities, and recognition of caves as analogs for extraterrestrial environments, raises the following questions:

- How can life survive in extreme environments found in glaciovolcanic cave systems?

- Is there pharmaceutical potential in any organisms present in glaciovolcanic cave systems?

- What can glaciovolcanic caves tell us about life on other solar system bodies and why can they be used as ana$\operatorname{logs}$ ?

We describe here the importance of answering these questions and illustrate research advances within the last decade.

While there has been substantial research on cave microbiology, studies have almost exclusively focused on karst-hosted systems (Hershey and Barton 2018). In contrast, studies of glaciovolcanic cave microbial ecology are rare, being limited to four studies of Mount Erebus and Mount St. Helens. The Erebus microbial communities comprise bacteria (Anitori et al. 2011; Tebo et al. 2015), algae (Fraser et al. 2018), and fungi (Connell and Staudigel 2013) as found in DOVE sediment samples from active fumaroles. The Mount St. Helens DOVE communities display many similarities with those found on Erebus, being dominated by aerobic bacteria capable of using chemoautotrophy and/or heterotrophy for growth. For example, genetic evidence suggests utilization of reduced inorganic 
molecules for energy, as found in trace volcanic gases $\mathrm{CO}$ and $\mathrm{H}_{2}$ coupled with autotrophic $\mathrm{CO}_{2}$ fixation mechanisms (Anitori et al. 2021). The above results confirm other published findings in glaciovolcanic cave environments (Fraser et al. 2014) which have revealed that microbes possess unique metabolic strategies that permit them to thrive in oligotrophic subsurface environments where higher-level organisms cannot survive.

Extreme environments, as found in glaciovolcanic caves, are increasingly being screened for new antimicrobials to combat the worldwide antibiotic crisis (Lewis 2020); drug-resistant infections could result in 10 million deaths annually by 2050 (O’Neill 2014). Bacteria cultured from the Mount St. Helens caves produced antimicrobial compounds in vitro (Anitori et al. 2021), indicating exciting potential for the discovery of new antibiotics to combat the antibiotic crisis (O'Neill 2014).

Glaciovolcanic caves also represent model systems for astrobiology, serving as excellent analogs for similar environments on Mars and other solar system bodies. For example, cave systems consisting of lava tubes are common on Mars (Cushing 2012). These cave environments could harbor evidence of past or present Martian microbes, as they would be shielded from the high-energy, organic molecule-destroying cosmic radiation that continuously bombards the Martian surface (Hassler et al. 2014; Pavlov et al. 2002). Therefore, terrestrial glaciovolcanic caves provide a suitable analog for studying life in Martian cave systems (Onstott et al. 2019). Moreover, terrestrial glaciovolcanic caves provide opportunities to test biological detection methods in low biomass, igneous substrates, and have served as analog testing sites for precursor robotic technologies for similar extraterrestrial environments. For example, the glaciovolcanic caves at Mount St. Helens and Mount Rainier proved essential to development of the NASA "Iceworm" robot (Curtis et al. 2018), and further concepts for lunar cave and lava tube exploration are being developed by NASA (e.g., Axel/DuAxel; Kerber and Nesnas 2016) and the European Space Agency (e.g., DAEDALUS; Rossi et al. 2021).

\section{Looking forward: perspectives for the coming decade}

Research on glaciovolcanism is expanding, and we suggest that studies of glaciovolcanic cave systems need to follow a similar trajectory. Glaciovolcanic cave systems are fascinating environments and most have never been visited by human beings, thus making them pristine and of extremely high value for research. Although all glaciovolcanic caves result from geothermal heat release, each system features individual characteristics, providing opportunities to probe a variety of processes and atmospheric/biologic interactions. In this regard, glaciovolcanic caves have formed in environments from polar regions (e.g., Mount Erebus,
Mount Rittmann, Mount Berlin) to temperate zones at high altitudes (e.g., Mount Rainier, Mount Hood, Mount Meager). Exceptions can be even found at low altitudes which are unusual for glacier development, as at Mount St. Helens. Each system is affected by different climate conditions, varying levels of hydrothermal activity, and/or physical mechanisms that result from their location on the volcanic edifice (e.g., crater or flank and aspect/orientation). However, all cases have a significant role to play in answering the following questions:

(1) How do glaciovolcanic caves interact with hydrothermal systems, and what can they tell us about the current state of volcanic activity and edifice stability?

(2) What survival strategies do extremophile cave microbes use, and are these organisms a source of new pharmaceuticals?

(3) How can they help in understanding extraterrestrial environments as analog testing sites?

Glaciovolcanic cave systems are likely to exist on many active, glaciated volcanoes worldwide (Fig. 1) including systems across Alaska, Kamchatka, Iceland, and several other regions. Research targeting glaciovolcanic caves in these regions should be prioritized in the future, as examining additional locations adds diversity to our existing knowledge and can help answer the questions which were discussed here.

Acknowledgements Thank you to J. Smellie and an anonymous reviewer, K. Cashman, associate editor, and A. Harris, executive editor for their constructive comments which improved the manuscript. Additional thanks to E. Cartaya for planning expeditions in the Pacific Northwest, USA, which facilitated those studies and expedition members B. McGregor, T. Wood, and E. Guth for the use of their photographs.

Author contribution LS and CS conceptualized and wrote the draft. All authors contributed to the text and the writing process, reviews, and provided feedback. LS prepared the figures. AP provided supervision of LS.

Funding Open Access funding enabled and organized by Projekt DEAL.

Open Access This article is licensed under a Creative Commons Attribution 4.0 International License, which permits use, sharing, adaptation, distribution and reproduction in any medium or format, as long as you give appropriate credit to the original author(s) and the source, provide a link to the Creative Commons licence, and indicate if changes were made. The images or other third party material in this article are included in the article's Creative Commons licence, unless indicated otherwise in a credit line to the material. If material is not included in the article's Creative Commons licence and your intended use is not permitted by statutory regulation or exceeds the permitted use, you will need to obtain permission directly from the copyright holder. To view a copy of this licence, visit http://creativecommons.org/licenses/by/4.0/. 


\section{References}

Anderson CH, Vining MR (1999) Observations of glacial, geomorphic, biologic, and mineralogic developments in the crater of Mount St. Helens, Washington. Wash Geol 27:9-19

Anderson CH, Behrens CJ, Floyd GA, Vining MR (1998) Crater firn caves of Mount St. Helens, Washington. JCKS 60:44-50

Anitori R, Davis R, Connell L, Kelley M, Staudigel H, Tebo B (2011) targeting autotrophic and lithotrophic microorganisms from fumarolic ice caves of Mt. AGU Fall Meeting Abstracts, Erebus

Anitori RP, Davis RE, Stenner C, McGregor B, Smith J, Cartaya E (2021) Glaciovolcanic cave microbial communities in the Mt. St. Helens eruption crater are dominated by bacteria and hold promise for antimicrobial discovery, World Microbe Forum, 20-24 June 2021

Badino G, De Vivo A, Piccini L (2007) Caves of sky, the journey in the heart of glaciers. Tintoretto, $153 \mathrm{p}$

Benn DI, Evans DJA (2010) Glaciers \& glaciation. Routledge, London, New York

Cannata A, Contrafatto D, Del Carlo P, Di Grazia G, Ferro A, Gambino S, Giudice G, Giuffrida G, La Spina A, Larocca G, Liuzzo M, Salerno G, Spampinato L, Zuccarello L (2018) Multidisciplinary investigation of Melbourne and Rittmann volcanoes. 20th EGU General Assembly, EGU2018, Proceedings from the conference held 4-13 April, 2018 in Vienna, Austria, p.6026

Connell L, Staudigel H (2013) Fungal diversity in a dark oligotrophic volcanic ecosystem (DOVE) on Mount Erebus, Antarctica. Biology (Basel) 2:798-809. https://doi.org/10.3390/biology2020798

Cuffey CM, Paterson WSB (2010) The physics of glaciers. Fourth edition. Amsterdam, etc., Academic Press. 704pp. J Glaciol 57:383384. https://doi.org/10.3189/002214311796405906

Curtis A (2016) Dynamics and global relevance of fumarolic ice caves on Erebus Volcano, Antarctica. Dissertation, New Mexico Institute of Mining and Technology

Curtis A (2020) Comparison of Earth's fumarolic ice caves, with implications for icy voids on other worlds [abs.]: 3rd International Planetary Caves Conference, San Antonio, Texas

Curtis A, Kyle P (2011) Geothermal point sources identified in a fumarolic ice cave on Erebus volcano, Antarctica using fiber optic distributed temperature sensing. Geophys Res Lett 38. https://doi. org/10.1029/2011GL048272

Curtis AG, Nash J, Higa S, Hoschchild JJ, Parness A (2018) Iceworm: ice climbing robots for glaciology and beyond. AGU Fall Meeting, 10-14 Dec 2018

Cushing G (2012) Candidate cave entrances on Mars. JCKS 74:33-47. https://doi.org/10.4311/2010EX0167R

Davis R, Anitori R, Stenner C, Smith J, Cartaya E (2020) Fumarolic glacial and firn ice caves on Mount St. Helens may provide insight into Martian subsurface microbial communities [abs.]: Analog Field Sites Mini Symposium, Houston, Texas. The Lunar and Planetary Institute, Open University Astrobiology, \& NASA Johnson Space Center

Duncombe J (2018) Meet IceWorm: NASA's new ice-climbing robot. Eos 99. https://doi.org/10.1029/2018EO111725

Edwards B, Kochtitzky W, Battersby S (2020) Global mapping of future glaciovolcanism. Glob Planet Chang 195:103356. https:// doi.org/10.1016/j.gloplacha.2020.103356

Florea LJ, Pflitsch A, Cartaya E, Stenner C (2021a) Microclimates in fumarole ice caves on volcanic edifices-Mount Rainier, Washington, USA. Geophys Res Atmos 126. https://doi.org/10.1029/ 2020JD033565

Florea LJ, Stenner C, Cartaya E, Pflitsch A, Sobolewski L, Ionescu A, Burgess S (2021b) The morphology of glaciovolcanic caves. GSA Am Abstr Programs 53:6. https://doi.org/10.1130/abs/ 2021AM-369695
Fraser CI, Terauds A, Smellie J, Convey P, Chown SL (2014) Geothermal activity helps life survive glacial cycles. Proc Natl Acad Sci U S A 111:5634-5639. https://doi.org/10.1073/pnas.1321437111

Fraser CI, Connell L, Lee CK, Cary SC (2018) Evidence of plant and animal communities at exposed and subglacial (cave) geothermal sites in Antarctica. Polar Biol 41:417-421. https://doi.org/10. 1007/s00300-017-2198-9

Gambino S, Armienti P, Cannata A, Del Carlo P, Giudice G, Giuffrida G, Liuzzo M, Pompilio M (2021) Chapter 7.3 Mount Melbourne and Mount Rittmann. Geol Soc Lond Mem 55:741-758. https:// doi.org/10.1144/M55-2018-43

Giggenbach WF (1976) Geothermal ice caves on Mt Erebus, Ross Island, Antarctica. N Z J Geol Geophys 19:365-372. https://doi. org/10.1080/00288306.1976.10423566

Gudmundsson MT, Sigmundsson F, Björnsson H (1997) Ice-volcano interaction of the 1996 Gjálp subglacial eruption, Vatnajökull, Iceland. Nature 389:954-957. https://doi.org/10.1038/40122

Gulley J (2009) Structural control of englacial conduits in the temperate Matanuska Glacier, Alaska, USA. J Glaciol 55:681-690. https://doi.org/10.3189/002214309789470860

Gulley JD, Fountain AG (2019) Glacier caves. In: White W, Culver D, Pipan T (eds) Encyclopedia of Caves, 3rd edn. Academic Press, Amsterdam, pp 468-473

Hassler DM, Zeitlin C, Wimmer-Schweingruber RF, Ehresmann B, Rafkin S, Eigenbrode JL, Brinza DE, Weigle G, Böttcher S, Böhm E, Burmeister S, Guo J, Köhler J, Martin C, Reitz G, Cucinotta FA, Kim M-H, Grinspoon D, Bullock MA et al (2014) Mars' surface radiation environment measured with the Mars Science Laboratory's Curiosity rover. Science 343:1244797. https://doi. org/10.1126/science. 1244797

Hershey OS, Barton HA (2018) The microbial diversity of caves. In: Moldovan OT, Kováč L, Halse S (eds) Cave Ecology, vol 235. Springer International Publishing, Cham, pp 69-90

Holmlund P (1988) Internal geometry and evolution of moulins, Storglaciären, Sweden. J Glaciol 34:242-248. https://doi.org/10.3189/ S0022143000032305

Ilanko T, Fischer TP, Kyle P, Curtis A, Lee H, Sano Y (2019) Modification of fumarolic gases by the ice-covered edifice of Erebus volcano, Antarctica. J Volcanol Geotherm Res 381:119-139. https:// doi.org/10.1016/j.jvolgeores.2019.05.017

Kerber L, Nesnas I (2016) The axel rover: a novel platform for instruments making measurements in extreme terrains: 3rd International Workshop on Instrumentation for Planetary Missions (2016). https://www.hou.usra.edu/meetings/ipm2016/pdf/4122. pdf. Accessed 17 June 2021

Kiver EP, Mumma MD (1971) Summit firn caves, Mount Rainier, Washington. Science 173:320-322. https://doi.org/10.1126/scien ce. 173.3994 .320

Kiver EP, Steele WK (1975) Firn caves in the volcanic craters of Mount Rainier. NSS Bull 37:45-55

Langmann B, Folch A, Hensch M, Matthias V (2012) Volcanic ash over Europe during the eruption of Eyjafjallajökull on Iceland, AprilMay 2010. Atmos Environ 48:1-8. https://doi.org/10.1016/j.atmos env.2011.03.054

Le Guern F, Ponzevera E, Yvette F, Lokey WM, Schroedel RD (2000) Mount Rainier summit caves volcanic activity. Wash Geol 28:25

Lewis K (2020) The science of antibiotic discovery. Cell 181:29-45. https://doi.org/10.1016/j.cell.2020.02.056

Lyon GL, Giggenbach WF (1974) Geothermal activity in Victoria Land, Antarctica. N Z J Geol Geophys 17:511-521. https://doi. org/10.1080/00288306.1973.10421578

Newhall CG (1996) IAVCEI/International Council of scientific unions' Decade Volcano projects: reducing volcanic disaster, status report. United States Geological Survey, Washington

O’Neill J (2014) Review on antimicrobial resistance. Antimicrobial resistance: tackling a crisis for the health and wealth of nations 
Onstott TC, Ehlmann BL, Sapers H, Coleman M, Ivarsson M, Marlow JJ, Neubeck A, Niles P (2019) Paleo-rock-hosted life on Earth and the search on Mars: a review and strategy for exploration. Astrobiology 19:1230-1262. https://doi.org/10.1089/ast.2018.1960

Pavlov AK, Blinov AV, Konstantinov AN (2002) Sterilization of Martian surface by cosmic radiation. Planet Space Sci 50:669-673. https://doi.org/10.1016/S0032-0633(01)00113-1

Pflitsch A, Cartaya E, McGregor B, Holmgren D, Steinhöfel B (2017) Climatologic studies inside Sandy Glacier at Mount Hood Volcano in Oregon, USA. JCKS 79:189-206. https://doi.org/10.4311/ 2015IC0135

Pierson TC, Janda RJ, Thouret J-C, Borrero CA (1990) Perturbation and melting of snow and ice by the 13 November 1985 eruption of Nevado del Ruiz, Colombia, and consequent mobilization, flow and deposition of lahars. J Volcanol Geotherm Res 41:17-66. https://doi.org/10.1016/0377-0273(90)90082-Q

Rossi AP, Maurelli F, Unnithan V, Dreger H, Mathewos K, Pradhan N, Corbeanu D-A, Pozzobon R, Massironi M, Ferrari S, Pernechele C, Paoletti L, Simioni E, Maurizio P, Santagata T, Borrmann D, Nüchter A, Bredenbeck A, Zevering J et al (2021) DAEDALUS - descent and exploration in deep autonomy of lava underground structures. Schriftenr Würzburger Forschungsberichte Robotik Telematik. https://doi.org/10.25972/OPUS-22791

Smellie JL, Edwards BR (2016) Glaciovolcanism on Earth and Mars: products, processes and palaeoenvironmental significance. Cambridge University Press, Cambridge

Sobolewski L, Stenner C, Hüser C, Berghaus T, Cartaya E, Pflitsch A (2022) Ongoing genesis of a novel glaciovolcanic cave system in the crater of Mount St. JCKS, Helens (in press)

Stenner C, Pflitsch A, Florea L, Graham K, Cartaya E (2022) The development and persistence of hazardous atmospheres within a glaciovolcanic cave system - Mount Rainier, Washington, USA. JCKS (in press)

Stenner C, Sobolewski L, Pflitsch A, Cartaya E (2021) Morphology of a new system of glaciovolcanic caves-Mount St. Helens. AGU Fall Meeting 2020. https://doi.org/10.1002/essoar.10505755.1

Stevens H (1876) The ascent of Mount Tahoma. Atlantic Monthly Nov:511-530

Sugden DE, John BS (1976) Glaciers and landscapes. Edward Arnold (Publishers) Ltd., London $376 \mathrm{p}$

Tebo BM, Davis RE, Anitori RP, Connell LB, Schiffman P, Staudigel $\mathrm{H}$ (2015) Microbial communities in dark oligotrophic volcanic ice cave ecosystems of Mt. Erebus, Antarctica. Front Microbiol 6(179). https://doi.org/10.3389/fmicb.2015.00179

Unnsteinsson T, Flowers G, Williams-Jones G (2021a) An analytical approach to understanding the morphologies of glaciovolcanic caves and chimneys. AGU Fall Meet 2020. https://doi.org/10. 1002/essoar.10505976.1

Unnsteinsson T, Flowers G, Williams-Jones G (2021b) Modelling the formation and evolution of glaciovolcanic caves and chimneys. EGU Gen Assembly 2021. https://doi.org/10.5194/egusp here-egu21-6821

Venugopal S, Moune S, Williams-Jones G, Wilson A, Russell JK (2017) Gas emissions and magma source of the Mount Meager Volcanic Complex, Garibaldi Volcanic Belt, BC. IAVCEI, Portland

Zimbelman DR, Rye RO, Landis GP (2000) Fumaroles in ice caves on the summit of Mount Rainier-preliminary stable isotope, gas, and geochemical studies. J Volcanol Geotherm Res 97:457-473. https://doi.org/10.1016/S0377-0273(99)00180-8 